\title{
Evaluation of runoff response on the basis of a comparative paired research in mountain catchments with the different land use: case study of the Blanice River, Czechia
}

VÁCLAV KRÁLOVEC, ZDENĚK KLIMENT, MILADA MATOUŠKOVÁ

Charles University in Prague, Faculty of Science, Department of Physical Geography and Geoecology, Prague, Czechia; e-mail: vaclav.kralovec@natur.cuni.cz, zdenek.kliment@natur.cuni. cz, milada.matouskova@natur.cuni.cz

ABSTRACT The paper evaluates the runoff response in two small mountain catchments on the basis of a comparative paired research in the headwater area of the Blanice River, south Bohemia. The predominantly grassy Zbytinský potok and forested Tetřívčí potok brooks represent the headwaters landscape of the eastern part of the Šumava Mountains. Differences in runoff response are observed on the principle of black box from the two points of view: long-term water balance characteristics and rainfall-runoff events. Despite the average lower runoff values, the forested Tetřívčí potok brook showed a more significant runoff response in most events, mainly in wet years, and the total higher variability of runoff. It has a significantly higher runoff during a dry period. The research is based on the own data obtained by continual monitoring of the water level, discharge and precipitation. The presented study wants to assess the differences in the behaviour of both hydrological systems, especially their response to a causal rainfall.

KEY WORDS small experimental catchments - hydrological balance - runoff variability rainfall-runoff events - Šumava Mts.

KRÁLOVEC, V., KLIMENT, Z., MATOUŠKOVÁ, M. (2016): Evaluation of runoff response on the basis of a comparative paired research in mountain catchments with the different land use. Case study of the Blanice River, Czechia. Geografie, 121, 2, 209-234.

Received January 2015, accepted January 2016.

CC Česká geografická společnost, z. s., 2016 


\section{Introduction}

Changes in hydrological regime are often discussed in the connection with the changes of our environment and landscape. Besides the impact of global (climatic) changes on rainfall-runoff process, the examined areas of smaller dimension are focused mainly on the impact of changes in land use and land cover. The changes become evident in water balance, extreme runoffs, soil moisture and evapotranspiration (Sikka et al. 2003). Assessment of the impact of the changes is crucial for strategic water resources management (Oudin et al. 2008) and for the policy development of water basin authorities (Croke, Jakeman 2001).

A lot of studies have dealt with the influences of changes in land cover. Detailed research papers were published by Hibbert (1967); Bosh and Hewlett (1982); Blažková (1991); Fohrer et al. (2001); Camorani, Castellarin, Brath (2005); Oudin et al. (2008); Saghafian et al. (2008); Malý (2009) or Nie et al. (2011). Hibbert (1967) concluded that catchment runoff response to the changes in land use is highly variable and mostly unpredictable. More than 30 years later, Kokkonen and Jakeman (2001) presented the fact that there were not any reliable models forecasting the influence of the change in land use on hydrological response in examined catchments. According to Oudin et al. (2008), only physically based hydrological modelling should be used to estimate land cover changes. Only such physically based models, whose reliability is patterned on physical equations which they are based on, should be used.

The influence of forested areas on runoff in catchments is also mentioned in an unclear way. The influence of forests on runoff has been investigated since the $19^{\text {th }}$ century. Early researches in small forested catchments were recorded in the Alpine area (Engler 1919). A long-term systematic research in comparative paired catchments $\left(\mathrm{ca} 4 \mathrm{~km}^{2}\right)$ in the area of the Javorníky Mountains has been done since the end of 1920s by Válek (1962). Unforested area of the Zděchovka catchment showed higher values of peak discharges, more dramatic discharge increase and decrease during a runoff event compared to the forested area of the Kychová catchment. In the period of low flow, the forested catchment improved its runoff. Rothacher (1973), having studied paired mountain catchments $\left(\mathrm{ca} 0.15 \mathrm{~km}^{2}\right)$ in Oregon, proved that peak discharges were higher in forested areas in the situations with a high antecedent precipitation index (API > $50 \mathrm{~mm}$ ). Hornbeck (1973) studied the changes of direct runoff volume for important discharge situations in Hubbard Brook Experimental Forest in New Hampshire. In the deforested catchment, he noticed increased volumes of direct runoff in the spring as a result of snow melting, but in the summer the proportion of the direct runoff was lower in the deforested catchment. Bíba et al. (2001) evaluated the impacts of vegetation changes on runoff in two forested mountain catchments, the Červík and the Malá Ráztoka catchments (ca $2 \mathrm{~km}^{2}$ ), in the Beskydy Mountains during almost 50-year 
long lasting monitoring. During the land cover regeneration, the runoff increase for low flows was recorded. The increase of peak discharges was not proved. The total runoff increase in the connection with deforestation was proved by Stednick (1996). Approximately the same runoff increase in a hydrological annual balance was recorded in catchments in the Rocky Mountains after removing $15 \%$ of forest as well as in catchments with the loss of $50 \%$ of forested areas in the area of the Central Interior Plains. The studies mostly describe the influence of forest in quite a wide range from very positive to hardly provable. The studies dealing with the negative effects of forests on runoff transformation of the catchment are very rare (Malý 2009).

The studies in small experimental catchments $\left(0.1-10 \mathrm{~km}^{2}\right)$ are more convenient for a detailed rainfall-runoff research. Mutual differences in the characteristics of studied catchments enable to watch influences of individual factors on the runoff process (Pavlásek, Máca, Ředinová 2006). We can observe the chosen problem better without any intervention of harmful effects in small homogenous areas and thus we can interpret our results on the basis of hydrological analogy for larger areas (Kř́ž 1978; Bosch, Hewlett 1982; Andréassian 2004). According to McCulloch and Robinson (1993), it is possible to carry out the experimental research in small catchments either within the same catchment or in more catchments. Studies in the same catchment compare data measured before and after carrying out an important change. Comparative studies are based on comparing information of two or more catchments. The method of a comparative paired catchment research is one of the most frequently used methods among comparative studies. The mutually compared catchments must be alike in terms of area and physical geography conditions, which is an elementary assumption of comparative paired catchment approach. The important thing is that the catchments must significantly differ in the examined attribute. Neighbouring catchments are usually chosen as we can easily consider the same causal conditions for the origin of rainfall-runoff event when regarding their close location and a small size of a studied area. We can find the examples of such approach in studies by Führer (1992), Hegg et al. (2004), von Stackelberg et al. (2007) or Archer (2007).

In the comparative paired research, the changes in long-term balance characteristics are monitored, e.g. Bosch and Hewlett (1982), Bíba et al. (2001), Watson et al. (2001), Brown et al. (2005) or Robinson and Dupeyrat (2005), as well as the differences during the chosen rainfall-runoff events, e.g. Sidle et al. (1995); Iroumé, Huber, Schulz (2005), Pavlásek, Máca, Ředinová (2006); García-Riuz et al. (2008) or Silveira and Alonso (2009). Individual attention is focused on the impacts of landscape changes in the water quality and in the overall ecohydrological condition of the streams (Robinson, Whitehead 1992; Langhammer, Kliment 2009; Langhammer, Matoušková, Kliment 2013). 
A significant part of runoff was linked with a slower catchment response on the rainfall event, presence of surface runoff was exceptional. On the contrary, the studies written by Czelis and Spitz (2003), Prudký (2003), Kuř́k (2000) and Tesař, Šír, Dvořák (2004) pointed out the significant influence of the type of land cover on the water retention during extreme precipitation (precipitation amount above $60 \mathrm{~mm}$ ) which cause surface runoff. According to Hümann et al. (2011), runoff generation and water retention in an area depend mainly on local specific and soil conditions. Soil conditions are an important parameter of evaluation in rainfallrunoff process. They determine not only the amount of infiltrated water but also the time of its retention in soil. At least two mechanisms of a rapid water transport in soil have been discovered. They are: percolating flow in coarse-grained soils (alternatively in fine-grained soils with the content of hydrophobic substances) and flowing in soil macropores. Both mechanisms are put into effect during the formation of runoff events in the mountainous areas of Czechia (Tesař, Šír, Dvořák 2004). These conditions have a greater influence on the runoff generation than the different type of forest. A contribution of forests to reduction of runoff and to the decrease of peak discharges is the most significant in case of small floods of frequent occurrence.

The aim of the submitted research was to evaluate runoff responses on the precipitation amount in differently used small mountain catchments of the Zbytinský Brook and the Tetříčí Brook in the source area of the Blanice River (southern Czechia). Both hydrological systems have been compared on the base of a comparative paired catchment research from the point of view of long-term regime characteristics and their variability as well as from the viewpoint of chosen short-term events. The null hypothesis was set for the chosen indicators. The null hypothesis is based on an assumption that both catchments are of geological, morphological and hydrological identity and that there is no significant difference in runoff response. On the contrary, the alternative hypothesis is expected to confirm the fact that there are substantial differences in runoff characteristics caused by different land use. The hypotheses have been verified by the chosen statistical tests.

\section{Methodology and source data}

\subsection{Characteristics of study catchments}

Mountain headwater areas are places where the runoff originate. These areas are in accordance with the occurrence of precipitation centres of the most disastrous floods and they also have decisive significance for preserving of discharge during the droughts. Even though the examined area is regarded to be close to naturally 


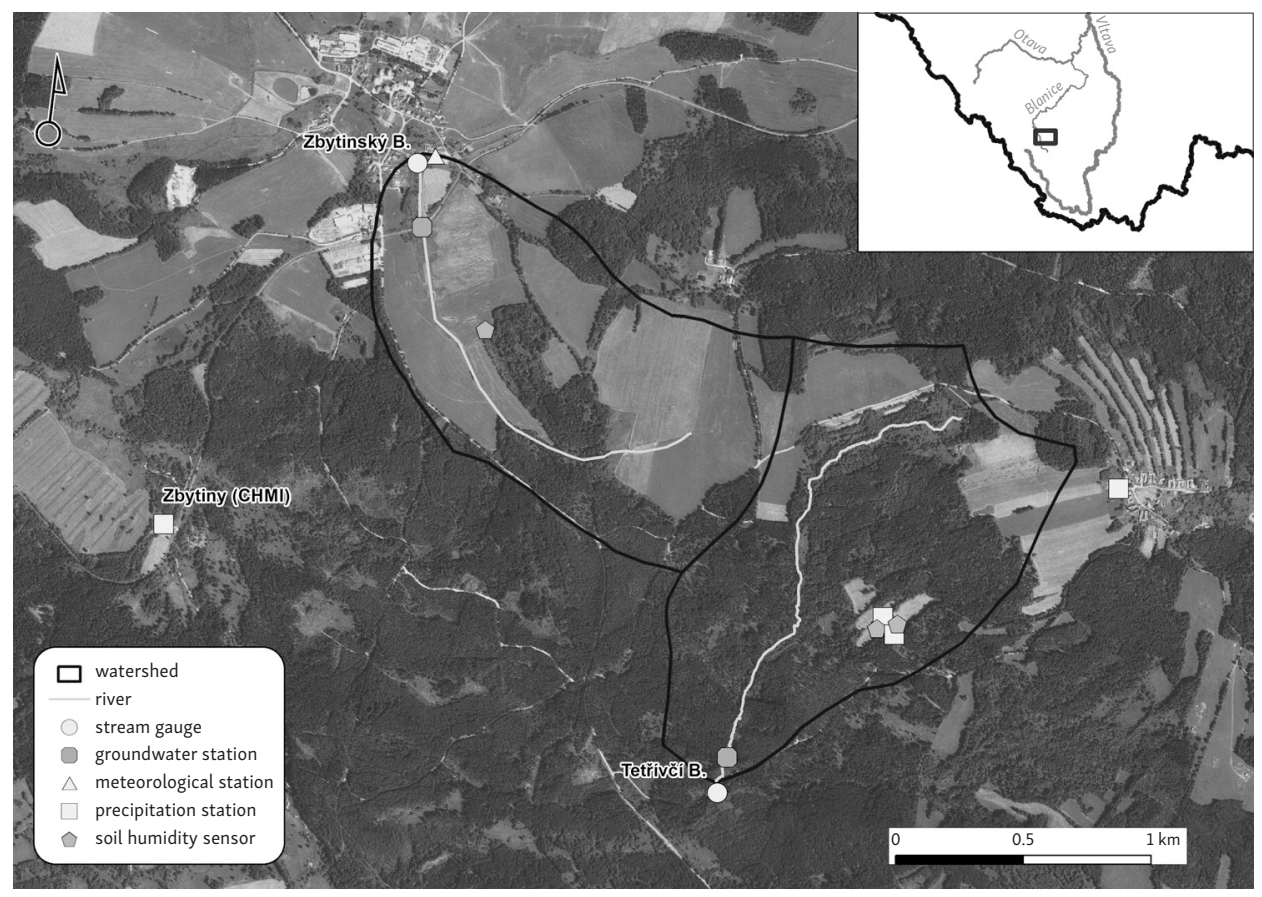

Fig. 1 - Location and area of study catchments. Data source: Charles University in Prague, Faculty of Science and WMS - Orthophoto, State Administration of Land Surveying and Cadastre.

forested or grassy environment, the landscape has been changed significantly during the last century (Kliment, Matoušková 2009; Vlček et al. 2012).

The paired catchments of the Zbytinský Brook (ZBY) and the Tetřívčí Brook (TET) are located in the source area of the Blanice River in the eastern part of the Šumava Mountains near the village of Zbytiny (Fig. 1). They both represent small neighbouring subcatchments with similar features of physical geography and hydrography in the altitudes between 785 and $946 \mathrm{~m}$ a.s.l. (Tab. 1). The catchments are very similar in their area, slope and exposure (prevailing western exposure) and they are also identical considering their geological bedrock in which Proterozoic to Palaeozoic metamorphic rocks prevail, especially granulites and orthogneisses. The banks of the streams are formed by the mixture of sand and silt sediments which turn to not well developed clay and partially peaty floodplain in the downstream part.

The TET is characterized by higher occurrence of Gleysols and Histosols (up to $20 \%$ of the catchment area), which pass into other soil types with less water influence (Stagnosol, gleyic Stagnosol) and to a typical Cambisol. Cambisols create up to $50 \%$ of the ZBY area. Entic Podzols are represented in upper part of both catchments, mainly in forested catchment. 
Tab. 1 - Hydrographic characteristics of study catchments

\begin{tabular}{lcc}
\hline Hydrographic characteristics & Zbytinský brook (ZBY) & Tetřívčí brook (TET) \\
\hline Catchment area [ $\mathrm{km}^{2}$ ] & 1.55 & 1.61 \\
Maximal altitude [m a.s.l.] & 906 & 946 \\
Minimal altitude [m a.s.l.] & 785 & 824 \\
Gravelius compactness coefficient & 1.15 & 1.18 \\
Slope [\%] & 9.71 & 9.59 \\
Thalweg [m] & 1,933 & 2,158 \\
Drainage density [km. $\mathrm{km}^{-2}$ ] & 1.25 & 1.33 \\
\hline
\end{tabular}
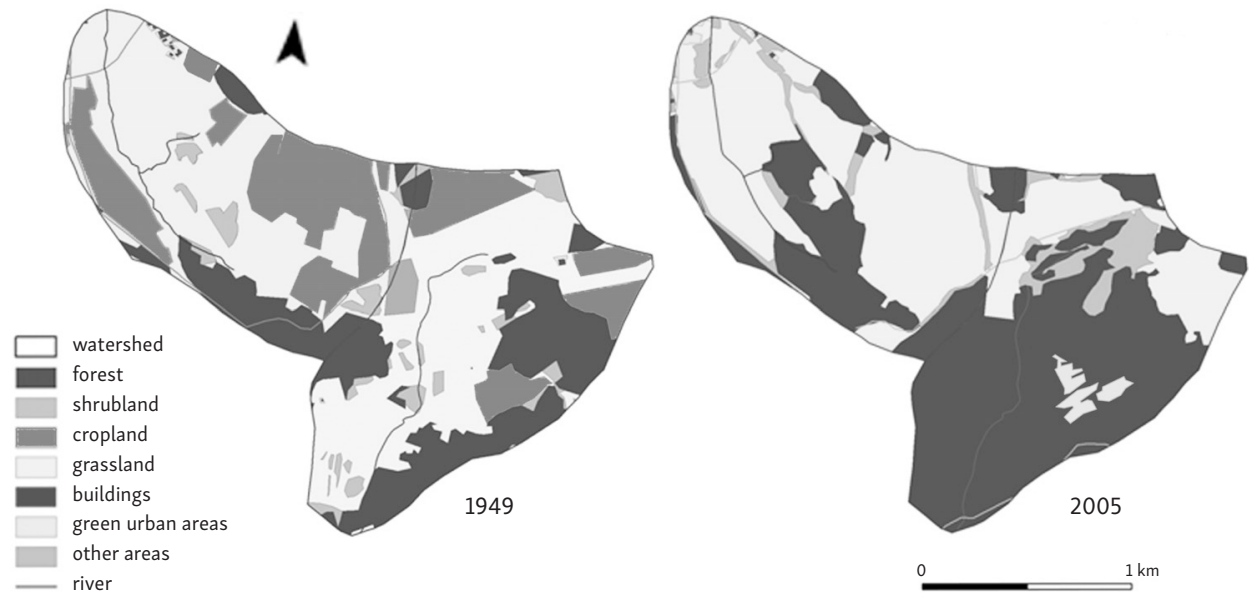

Fig. 2 - Development of land use in study catchments (1949-2005). Source: Hintnaus 2008.

The catchments differ in land cover and in the presence of soil types. The ZBY is represented mostly by meadow habitat. $56 \%$ of the catchment area is made up by mowed meadows, $7 \%$ is represented by natural meadows and almost $35 \%$ is covered by forests with spruce predominance. The TET is characterized mostly by forest habitat. Forests cover $68 \%$ of its area ( $48 \%$ coniferous forest with spruce predominance, $15 \%$ mixed forest, $5 \%$ broadleaf forest), $11 \%$ is made up by natural meadows with the penetration of shrubs and trees, $17 \%$ is covered by mowed meadows. Both catchments have experienced significant changes in land use and landscape structure during the last 60 years. Hintnaus (2008), whose work was based on the analysis of aerial photos, confirmed the decrease of arable land (30\% of the ZBY and $16 \%$ of the TET were covered by arable land in 1947) that resulted in benefit of grasslands and forests (Fig. 2).

Earlier intensive farming activities from the second half of the $20^{\text {th }}$ century in the ZBY are supported by the existence of subsurface drainage pipe network. The drained area originally covered $21 \%$ of the catchment area. Nowadays, the drained 

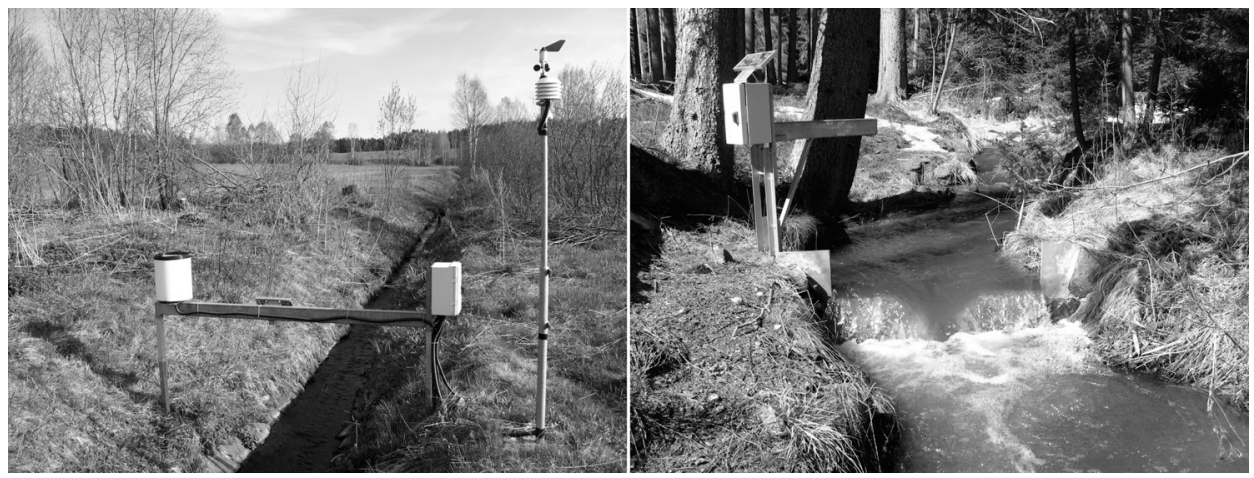

Fig. 3 - Meteorological station and water-level measure - The ZBY Brook (left), water-level measure - the TET Brook (right)

area is covered by a mowed meadow and a drainage pipe system is disrupted in a few places. In the middle and the bottom part of the TET, there is a dense surface network of man-made drainage channels. Those drainage channels originated in the historic times when the examined area was inhabited and farmed by German native speakers and the proportion of forests was much smaller than today. The above mentioned network of the intermittent channels has not been maintained anymore and it is often blocked off by dead wood.

\subsection{Monitoring network and data sources}

Monitoring of rainfall-runoff processes is based on the own automatic monitoring network, which has been gradually developed since the year 2006. It consists of 2 stream gauge stations with ultrasonic and hydrostatic pressure sensors, 1 fully equipped meteorological station (precipitation, air temperature, air moisture, wind speed and wind direction, solar radiation) and other 3 precipitation stations. The data are stored in a ten-minute interval and they are transferred to a storage server using GPRS network. There is a manual precipitation station Zbytiny nearby, belonging to Czech Hydrometeorological Institute (CHMI), where the earliest measurements were recorded in 1984. Its data are used to evaluate trends in precipitation and to validate measured data from automatic rain gauges. Monitoring of water levels has been taking place in the outlets of the researched brooks. The straightened ZBY has a regular paved trapezoid profile. The natural profile of the forested TET streambed has been placed with the measuring spillway (combination of Thompson - Poncelet - Fig. 3). Water level measurement is supplemented by systematic hydrometric measurements of discharges for deriving a relevant rating curve. 

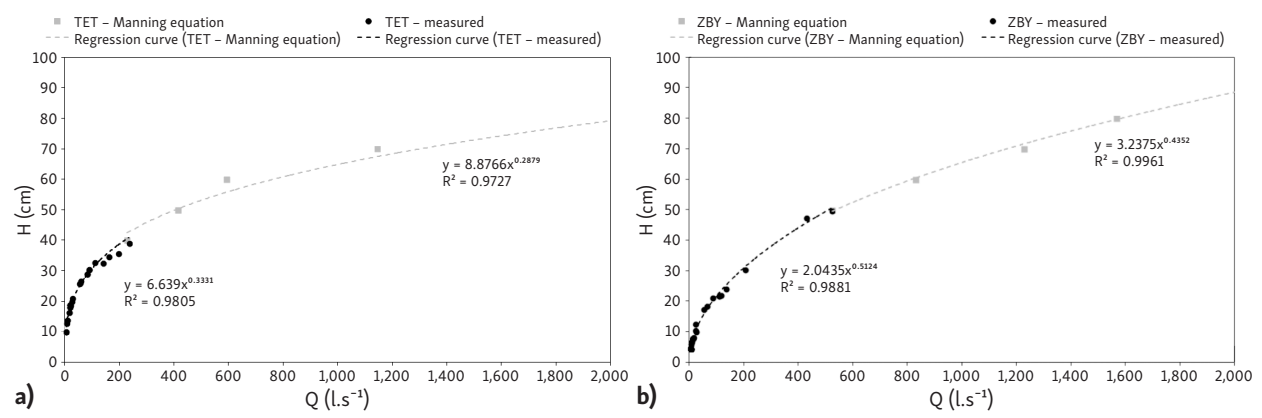

Fig. 4 - Derived rating curves for TET Brook (a) and ZBY Brook (b)

The extrapolation of rating curves above the threshold of figures measured so far (in the ZBY $50 \mathrm{~mm}$, in the TET $40 \mathrm{~mm}$ ) has been carried out on the base of calculation of the discharge speed using the Manning equation and the corresponding size of flowing area. The values of the Manning roughness coefficient were derived during the hydrometric measurements. For rating curves of both profiles, and the derived relations for discharge conversion (Fig. 4).

The average specific discharges per evaluated hydrological event 2007-2012 are $13.691 . \mathrm{s}^{-1} . \mathrm{km}^{-2}$ for the ZBY and $10.271 . \mathrm{s}^{-1} \cdot \mathrm{km}^{-2}$ for the TET (Tab. 2). The maximum immediate culminations have reached in a short-term period the highest values during the event of the $6^{\text {th }}$ of July, 2012 in the ZBY on the level of $646 \mathrm{~mm}$ (it corresponds with the specific discharge of $6251 . \mathrm{s}^{-1} \cdot \mathrm{km}^{-2}$ ), and $719 \mathrm{~mm}$ in the TET (corresponding with the specific discharge of $9271 . \mathrm{s}^{-1} \cdot \mathrm{km}^{-2}$ ). The levels above the

Tab. 2 - Precipitation and hydrologic characteristics

\begin{tabular}{|c|c|c|c|c|c|c|c|}
\hline ZBY & 2007 & 2008 & 2009 & 2010 & 2011 & 2012 & 2007-2012 \\
\hline $\mathrm{q}\left[\mathrm{l} \cdot \mathrm{s}^{-1} \cdot \mathrm{km}^{-2}\right]$ & 9.25 & 13.86 & 15.09 & 15.83 & 12.50 & 13.64 & 13.69 \\
\hline$q_{d} \max \left[1 . s^{-1} \cdot \mathrm{km}^{-2}\right]$ & 149.29 & 139.89 & 222.40 & 84.27 & 57.65 & 94.21 & 222.40 \\
\hline$q_{d} \min \left[l . s^{-1} \cdot \mathrm{km}^{-2}\right]$ & 2.50 & 3.70 & 5.42 & 7.28 & 7.25 & 6.69 & 2.50 \\
\hline precipitation $[\mathrm{mm}]$ & $808^{*}$ & 841 & 972 & 867 & 742 & 843 & 845 \\
\hline runoff coefficient [\%] & 0.36 & 0.52 & 0.49 & 0.58 & 0.53 & 0.51 & 0.51 \\
\hline \multicolumn{8}{|l|}{ TET } \\
\hline $\mathrm{q}\left[\mathrm{l} \cdot \mathrm{s}^{-1} \cdot \mathrm{km}^{-2}\right]$ & 7.31 & 9.75 & 12.76 & 13.25 & 8.04 & 8.44 & 10.27 \\
\hline $\mathrm{qd}_{\mathrm{d}} \max \left[\mathrm{l} \cdot \mathrm{s}^{-1} \cdot \mathrm{km}^{-2}\right]$ & 189.75 & 132.11 & 281.79 & 126.92 & 53.75 & 101.36 & 281.79 \\
\hline$q_{d} \min \left[l . s^{-1} \cdot k^{-2}\right]$ & 3.30 & 3.96 & 4.31 & 5.87 & 4.02 & 4.13 & 3.30 \\
\hline precipitation [mm] & $808^{*}$ & 842 & 976 & 881 & 734 & 829 & 845 \\
\hline runoff coefficient [\%] & 0.29 & 0.37 & 0.41 & 0.47 & 0.35 & 0.32 & 0.38 \\
\hline \multicolumn{8}{|l|}{ ZBYTINY (CHMI) } \\
\hline precipitation $[\mathrm{mm}]$ & 803 & 862 & 974 & 882 & 751 & 863 & 856 \\
\hline
\end{tabular}

Data source: Charles University in Prague, Faculty of Science and CHMI

Note: * precipitation from ZB2 station only 
Tab. 3 - Relation for the calculation of areal precipitation within the catchment

\begin{tabular}{ll}
\hline Catchment & Equation for the calculation of precipitation \\
ZBY & $\mathrm{H}_{\text {ZBY }}=0.489 \times \mathrm{ZB} 2+0.295 \times \mathrm{LOU}+0.216 \times \mathrm{KOR}$ \\
TET & $\mathrm{H}_{\text {TET }}=0.101 \times \mathrm{ZB} 2+0.686 \times \mathrm{LOU}+0.213 \times \mathrm{KOR}$ \\
\hline
\end{tabular}

hydrometric measurements in the period of rainfall-runoff episodes ranged from tens of minutes to one or maximum two hours.

For each catchment, areal precipitations have been calculated using IDW method where the input data for the calculations were coming from 3 stations (closing profile of the ZBY - ZB2, the eastern border of the TET in the village Koryto - KOR, the middle part of the TET - LOU). Calculated areal precipitations have been related to the centroid of the particular catchment. The relations used for the calculations of areal precipitations in both catchments are shown in the Table 3. Taking into consideration small areas of both catchments, the proximity of all the rain gauges and similar precipitation figures, there was not given any other specification (besides linear distance) for setting weights for individual rain gauge.

An annual long-term mean precipitation amount at Zbytiny (CHMI) station is $770 \mathrm{~mm}$ (hydrological period 1984-2012). The highest maximum of precipitation amount $(1,386 \mathrm{~mm})$ was recorded in the time of occurrence of the disastrous flood in Czechia in 2002, the lowest minimum was recorded in 1991 (573 mm). The existing period of experimental monitoring can be described as above-average one with the range of annual precipitation amount at Zbytiny (CHMI) station between 751 and $974 \mathrm{~mm}$ (Tab. 2).

The most abundant precipitation year of our experimental season was the year 2009. The precipitation maximum was recorded during this year in the researched area, when the record of the rainy episode was $104 \mathrm{~mm}$ from June, $22^{\text {nd }}$ to June, $23^{\text {rd }}$ in 2009. On the contrary, the maximum of mean specific discharge was recorded in the year 2010. It is necessary to say that the stated figures are related only to relatively short time period of 2007-2012.

\subsection{Analysis of rainfall-runoff regime}

Rainfall-runoff relationships and differences in runoff responses of both catchments were observed on the principle of black box from two points of view: (1) on the basis of average balance characteristics and the rate of runoff variability, (2) on the analysis of chosen rainfall-runoff events. From the viewpoint of average characteristics, there was the calculation of monthly, annually and long-term runoff and rainfall parameters and runoff coefficient. There were used self-measured time series and derived rating curves. 
Runoff variability was evaluated, besides traditionally used methods (flow duration curve, decile deviation $\mathrm{D} / \mathrm{Qr}$, coefficient of variation $\mathrm{Cv}$ ), using flashiness index FI (Baker 2004) and analysis of hydrological disturbance (Archer 2007). Index FI is a dimensionless number which can reach values from 0 to 2 . This index expresses how discharge was changed between the two time units (days, hours) and is calculated according to the following equation:

$$
F I=\frac{\sum_{i=n}^{n}\left|q_{i}-q_{i-1}\right|}{\sum_{i=1}^{n} q_{i}}
$$

The letter $q$ stands for an average discharge and $i$ is the successive number of the day or the hour. The value of 0 means absolutely constant discharge. The higher value the FI reaches, the more variable discharge is.

Analysis of hydrological disturbance is based on the examining of frequency and time duration, so called pulses, i.e. states when a certain threshold value of discharge ( $\mathrm{x}$-multiple of median discharge in an hour step) is reached or exceeded. The time duration of one pulse is determined as the time between exceeding a certain threshold value and the following decrease below the same threshold value of discharge.

Mean daily discharges were used to calculate daily rating curves and individual statistic indexes. On the contrary, mean hourly discharges were used for analysis of hydrologic disturbance. The chosen indexes (outflow coefficient, coefficients of variability) were tested by double-choice t-test.

The evaluation of rainfall-runoff events was based on the detailed analysis of hyetograph and hydrograph of chosen rainfall-runoff events (Malý 2009; Pavlásek, Máca, Ředinová 2006). The elementary assumption was that recorded differences in runoff response in both catchments will be caused mainly as a consequence of different land cover and the land use of the area, when regarding identical causal and physical geographical conditions. Necessary pre-processing of time series including analysis and following choice of rainfall events was done before the choice of evaluated rainfall-runoff events. The rainfall event was defined by its minimum height of precipitation amount and the maximum time duration of non-precipitation period. The first criterion fully eliminates insignificant precipitation amounts; the other criterion separates rainfall events from one another. The minimum height of precipitation amount was set with the value of $\mathrm{H}_{\mathrm{s}} \geq 9 \mathrm{~mm}$ and the maximum time duration of non-precipitation period was set at 50 minutes. During this precipitation amount, there was recorded sufficient increase in water level at both streams and there was not any hydrological recording influenced by any mistake in our measurements. Only events occurring during the warm half a year were evaluated. The following criteria were used for identification of evaluated rainfall-runoff events: 
- The runoff events produced single hydrographs, without multiple peaks.

- Rainfall totals and rainfall time distribution in both catchments were equal or very similar.

- Complete precipitation and discharge data were available during the whole time of event.

- There were evaluated only events, for which the discharges were derived reliably on the basis of a rating curve.

40 rainfall-runoff events were chosen according to the criteria mentioned above. The set of causal and dependent variables was calculated for each of the chosen rainfall-runoff events. Four factors, which explained the variability of detected causal conditions in the catchments, were chosen using the principal component analysis from originally selected set of causal variables. These were primarily precipitation characters: duration time $T_{h}(\mathrm{~min})$, precipitation amount $H_{s}(\mathrm{~mm})$, average intensity $I_{p}\left(\mathrm{~mm} \cdot \mathrm{h}^{-1}\right)$ and catchment saturation expressed by the antecedent precipitation index API 30. These factors created input data for subsequent cluster analysis, on which basis there were derived the most frequently occurring types of causal conditions, during which significant runoff situations are created

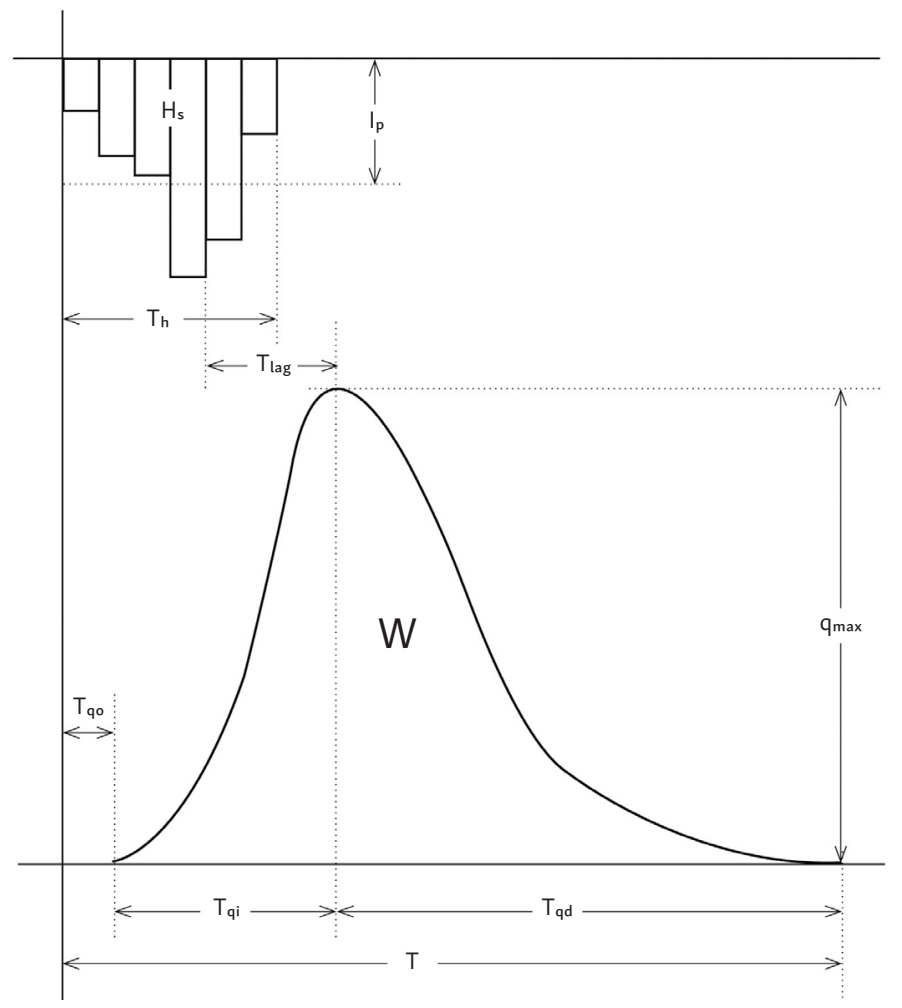

Fig. 5 - Evaluated characteristics of hyetograph and hydrograph 
in both catchments. The method of tree clustering using the WARD algorithm for determination of objects similarity and the distance between them (squared Euclidean distance) was applied.

Seven indicators sufficiently expressing the behavior of the hydrological system were chosen from the set of disposable dependent variables (Fig. 5). $T_{q 0}$ is defined as the duration time between the beginning of precipitation and the start of rising limb of the hydrograph. $T_{q i}$ is the duration time of the rising limb of the hydrograph; $T_{q d}$ is the duration time of the recession limb of the hydrograph till the end of the direct runoff (the point of inflection on the recession limb). $T$ is defined as the total duration time of rainfall-runoff event from the beginning of precipitation till the end of the direct runoff. $T_{\text {lag }}$ is the lag time (duration time between the maximal intensity of precipitation and the peak discharge), $q_{\max }$ is the specific peak discharge, $W$ is the direct runoff volume in the event. The values of observed dependent variables were consequently compared among each other and they were tested according to the individual types of causal conditions (independent two-sample t-test, Mann-Whitney test) between both catchments.

\section{Results}

\subsection{Water balance and runoff variability}

The first estimations of hydrological balance were specified for both catchments for period 2007-2012. Runoff coefficient in forested TET was significantly lower than in the ZBY. It was lower for the total evaluated period as well as within each year (Tab. 2). On average, there was of $13 \%$ less water volume from precipitation running off the TET and of $18 \%$ less during the year 2011 (the less abundant precipitation year). The value of the runoff coefficient fluctuated depending on the precipitation amount and the season where the higher variability between cold and warm period was identified in unforested ZBY. The greatest differences in the value of the runoff coefficient between the two catchments were in the winter and spring seasons (Fig. 6). On the contrary, the lowest values and the smallest differences were found out in the summer months in which the majority of rainfall-runoff events were concentrated. The differences in runoff coefficient between the two catchments proved to be statistically important. Only in the warm half of the year, the recorded difference was not significant.

As we can see, the flow duration curves are shaped similarly for both monitored streams (Fig. 7). Most of the year forested TET showed lower runoff values than the ZBY. More significant differences became evident: (1) in the period of low flows (dry conditions) when the forested catchment, especially in years with lower discharge, significantly improved its discharge, (2) in the period of high flows 
Tab. 4 - Statistical indicators of runoff variability calculated from mean daily values (2007-2012)

\begin{tabular}{lcccccccc}
\hline Year & \multicolumn{2}{c}{ FI } & & \multicolumn{2}{c}{ D/Qr } & & \multicolumn{3}{c}{ CV } \\
\cline { 2 - 3 } \cline { 7 - 9 } & ZBY & TET & & ZBY & TET & & ZBY & TET \\
\hline 2007 & 0.299 & 0.307 & & 0.191 & 0.116 & & 1.117 & 1.476 \\
2008 & 0.232 & 0.321 & & 0.152 & 0.136 & & 0.833 & 1.001 \\
2009 & 0.303 & 0.398 & & 0.163 & 0.191 & & 1.185 & 1.630 \\
2010 & 0.164 & 0.333 & & 0.099 & 0.194 & & 0.521 & 1.047 \\
2011 & 0.127 & 0.230 & & 0.089 & 0.129 & & 0.399 & 0.700 \\
2012 & 0.206 & 0.342 & & 0.095 & 0.125 & & 0.572 & 0.998 \\
\hline $2007-2012$ & 0.219 & 0.329 & & 0.137 & 0.142 & 0.831 & 1.281 \\
\hline
\end{tabular}

Data source: Charles University in Prague, Faculty of Science

(wet conditions) when the forested catchment, especially in years with higher discharge, showed more significant runoff responses. The difference in the two catchments behaviour is expressed also by mean values of statistical indicators of runoff variability, including flashiness index FI. They reach higher values in the forested catchment when regarding not only individual years but also the whole monitored period (Tab. 4). The discovered differences were statistically significant for $F I$ and $C v$ parameters.

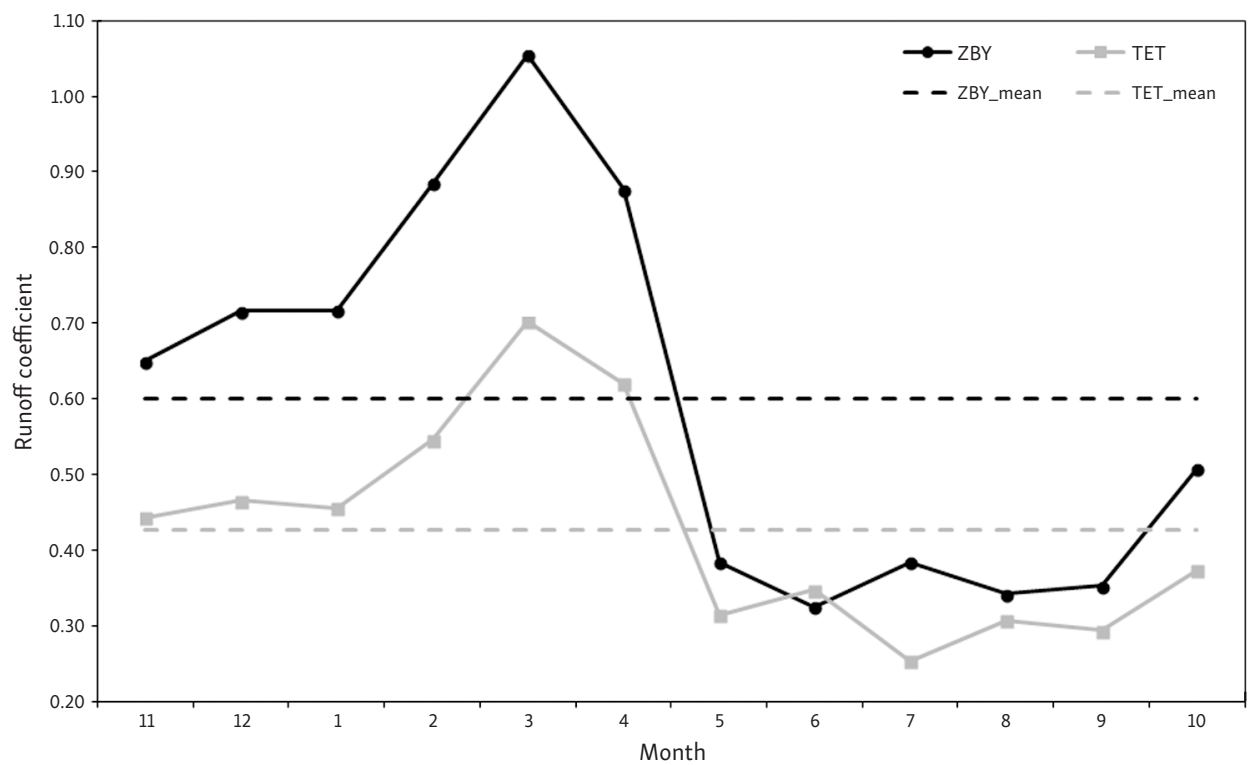

Fig. 6 - Average monthly values of the runoff coefficient (2007-2012). Data source: Charles University in Prague, Faculty of Science. 

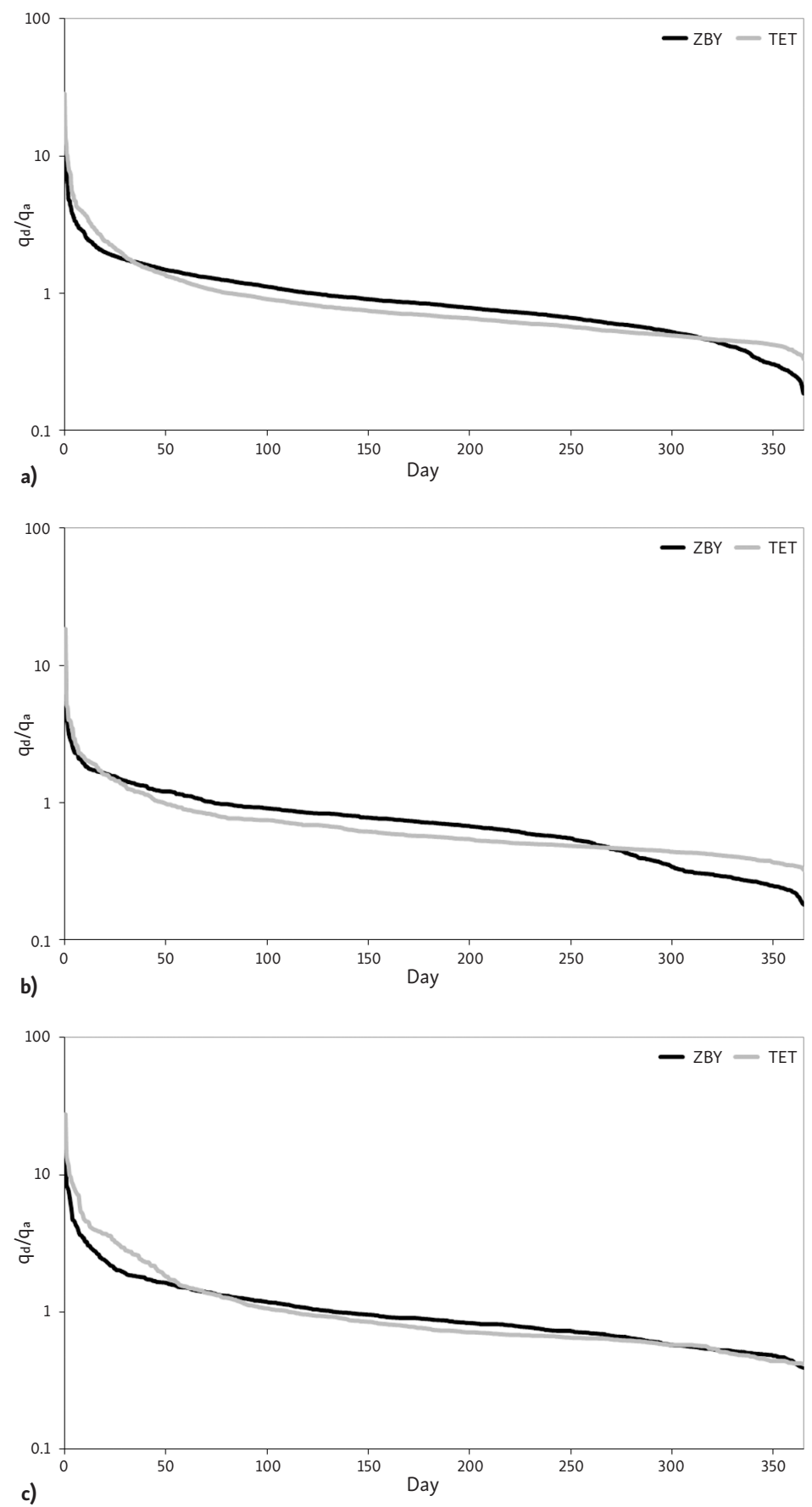

Fig. 7 - Flow duration curves for the whole period 2007-2012 (a), for years of lower discharge (b) and for years of higher discharge (c). Data source: Charles University in Prague, Faculty of Science. 

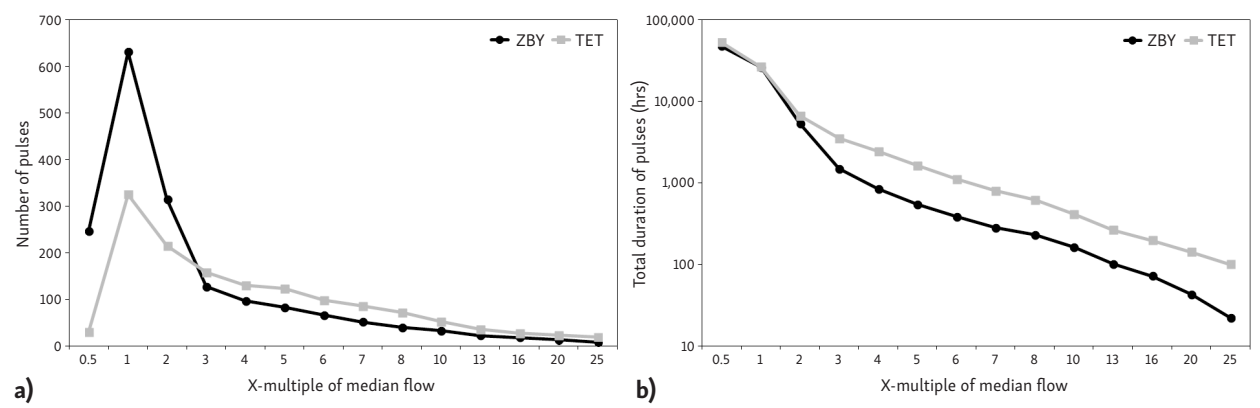

Fig. 8 - Number (a) and total duration time (b) of pulses for the chosen values of flow threshold (2007-2012). Data source: Charles University in Prague, Faculty of Science.

Interesting results were carried out by the analysis of hydrological disturbance based on the frequency and duration time of pulses above threshold flows (Archer, Newson 2002). The relation between the number of pulses and the size of flow threshold is shown in the Figure 8. The greatest number of pulses was reached in the size category $1 \mathrm{M}$. When the size of thresholds increases, the number of pulses is smaller. It is caused by less frequent of higher flows. On the contrary, when the flows are lower than the value $1 \mathrm{M}$, the number of pulses gets smaller due to the increase of duration time and the coupling of individual pulses. The number of pulses up to the value $2 \mathrm{M}$ (twice of the median of discharge) is significantly greater for unforested ZBY, in the interval including values from $3 \mathrm{M}$ to $10 \mathrm{M}$ is recorded a bit greater number of pulses in forested TET. Above the threshold value of $10 \mathrm{M}$ the number of pulses is very similar for both catchments.

A more detailed analysis of annual cycles of pulse number showed close relationship between the number of pulses and the runoff quantity of the year. The most pulses were recorded in years with higher discharge 2009 and 2010, and the least number of pulses was recorded in years with lower discharge 2007 and 2011. The years with higher discharge were characterized by higher variability of runoff. The duration time of pulses up to the value $2 \mathrm{M}$ is almost identical in both catchments. But the more increasing discharge is, the greater the differences in the duration time are. The average duration time of the pulse is longer in the forested TET. It proves more significant runoff response in this catchment during the period of higher flows.

\subsection{Analysis of rainfall-runoff events}

Based on the analysis of causal factors for 40 evaluated events, there were defined (using the cluster analysis) four types of causal situations (rainfall regimes): 
S1 - short term rainfall of average intensity at the lower saturation of the catchment (overall 13 events), S2 - long term rainfall of smaller intensity at the low saturation of the catchment (overall 6 events), S3 - rainfall of smaller intensity with average duration time and total precipitation at the higher saturation of the catchment (overall 10 events) and S4 - short term heavy rainfall at the higher saturation of the catchment (overall 6 events). The remaining 5 events were not classified. In the Table 5 , there are shown mean values of chosen causal factors and the corresponding parameters of the hydrograph. Arithmetic mean was calculated for the parameters, whose values corresponded with normal distribution. Median was chosen for those parameters whose distribution did not meet needs of normality and thus the extreme values could be eliminated. Differences in runoff response of both catchments have been quantified by a variance between the standardized mean values of hydrograph parameters in the both catchments. Standardization was carried out in a way that each value of a particular parameter for both catchments was expressed as one per cent of the average value from all of those possible episodes. Absolute difference of those standardized mean values made the final deviation. On the base of the gained proportional differences, there was created our own classification defining the size of difference between both catchments. When the difference of the values for the ZBY and the TET was up to $5 \%$, the observed parameter was regarded as an identical one, i.e. the catchments did not differ in that. When the proportional deviation was more than $30 \%$, the calculated difference in that particular parameter was described as a very distinctive one. The comparisons of runoff responses in the two catchments for the given type of causal situation are shown in the Table 6.

For each monitored parameter of the hydrograph, the following findings emerged:

- $T_{q o}$ - the time of runoff response to the precipitation is very similar in both catchments, the response appears to be faster in the TET during the short term rainfall.

- T, $T_{q d}$ - duration time of the recession limb of hydrograph and at the same time of the complete rainfall-runoff event is in all causal situations in the TET significantly longer.

- $T_{q i}$ - duration time of the rising limb of hydrograph is in all types of causal situations comparable and there are no recorded differences between the catchments.

- Tlag - with the decrease of the catchment saturation, the difference in the duration time between the maximal intensity of precipitation and peak discharge increases in favour of forested TET. The greatest difference is recorded for the type S1. The differences are not significant when the catchment saturation is higher and during the long term rainfall.

- $q_{\max }$ - specific peak discharge differs according to the type of causal situation, where the important thing is the saturation of the catchment. Higher peak 


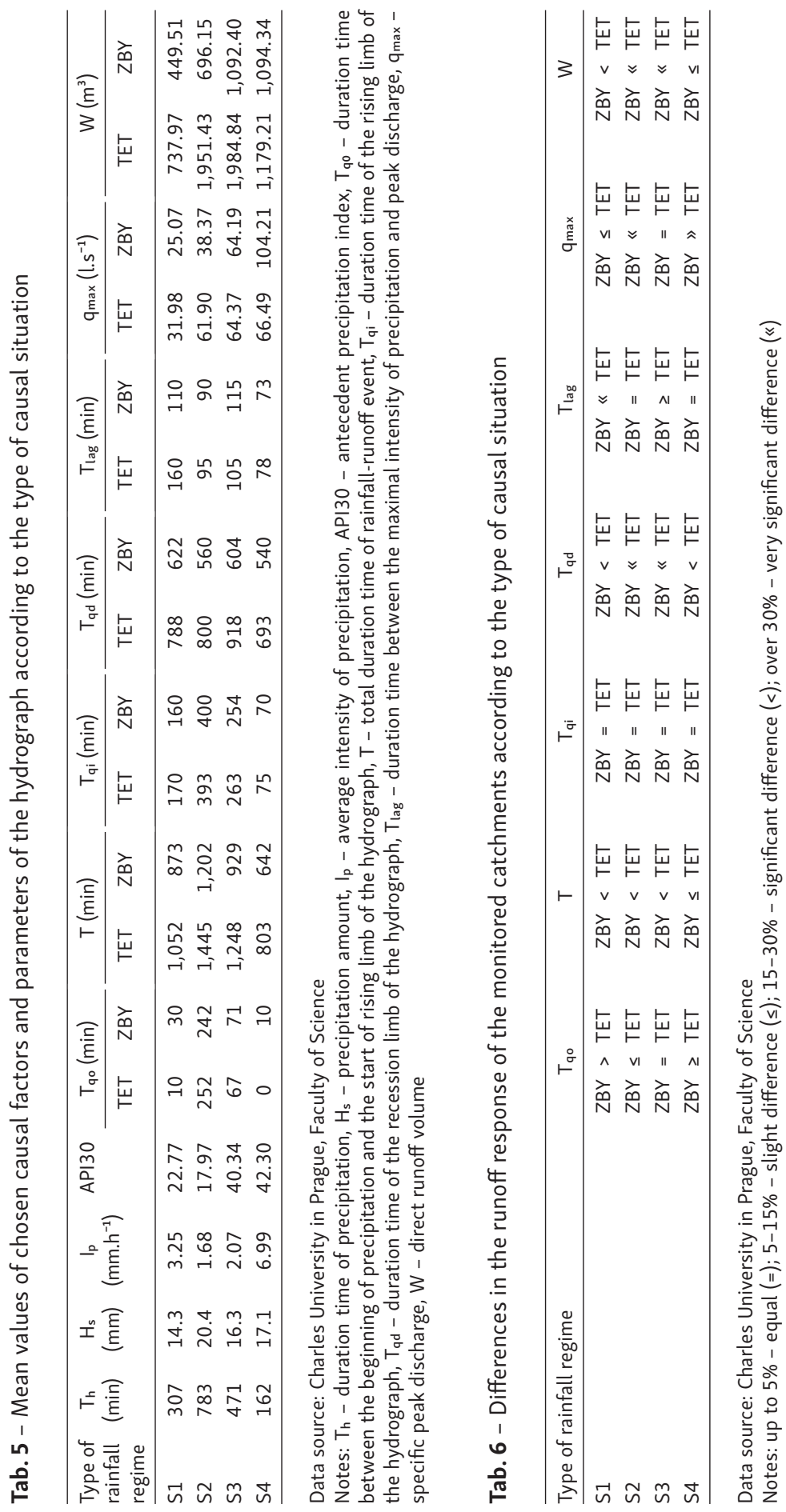


discharges were observed in the TET at the lower catchment saturation, especially during long-term precipitations. Peak discharges were significantly higher in the ZBY only during short term heavy precipitations at the higher saturation of the catchment.

- $W$ - the direct runoff volume is closely related to the duration time of rainfallrunoff event and it is overall significantly greater in the TET.

The differences in chosen parameters of the hydrograph for each causal situation were the subject of testing of statistic hypotheses. Null hypothesis was formulated in a way that between the observed parameters of the hydrograph, i.e. in the runoff response of the two catchments, there is no significant difference. The significance level of 0.05 was chosen for the testing. The null hypothesis was confirmed for all of the indices. There was not proved any significant difference from the statistic point of view in the runoff response in the both monitored catchments on the base of evaluated events.

\section{Discussion}

The presented study deals with the evaluation of runoff response in differently used small mountain catchments on the base of comparative paired catchment research. The choice and the location of observed catchments were chosen in such a way that the catchments are nearly identical regarding their conditions, but they must differ especially in the terms of land cover and land use. Despite this fact, the other runoff influencing factors will never be the same in natural conditions. We must also take account of the fact that the TET represents the area with the predominance of forests but not absolutely forested area and similarly the ZBY represents prevailing meadow environment. During the last 60 years many changes in land use of both catchments have been done. Remnants of the previous economic activities, particularly the systems of surface and subsurface drainage, can influence the runoff process at present.

The evaluation of rainfall-runoff process is based on the approach of black box, thus without any detailed assessment of individual runoff influencing factors for the present. The analyses of time series come out of our own continually measured data of 6-year period observations. So far, relatively short time series of observations does not have to be, in comparison with other similarly focused studies, sufficiently representative for their evaluation and standardization with regard to the number of analyzed rainfall-runoff events. Even though the data have been going through accurate supervision, there is still partial uncertainty in deriving of values of discharges above the threshold established by hydrometric measurements. Just only the data of higher runoff are needed to be more accurate. 
That is the reason why the extreme runoff events have not been evaluated so far in a detailed analysis of rainfall - runoff episodes.

Realized analyses pointed out the differences in rainfall-runoff process in the comparative paired catchments. The greatest differences are found in average water balance characteristics, where in accordance with findings of Brown et al. (2005), Robinson and Dupeyrat (2005), Garcia-Ruiz et al. (2008), the total annual runoff is smaller in the forested catchment above all in winter and spring seasons. In conformity with Brown et al. (2005), this phenomenon can be attributed to the higher rate of interception and evapotranspiration of the forest, especially coniferous forest. During summer seasons when rainfall-runoff events are the most frequented, the differences are not so significant from the long-term point of view or there are no differences at all.

The analysis of flow duration curves proved that the forested catchment, particularly in years with lower discharge, significantly improved low flows. On the other hand, during the years with higher discharge, it showed more significant runoff responses increasing with the significance of events. The more significant runoff responses from the forested TET are probably the main cause of higher runoff variability from the forested catchment. We can also find a claim about a positive influence of forested habitat on water retention in dry periods in the contribution by Válek (1962), who published his results more than 50 years ago. The more significant runoff responses from forested habitat during wet seasons are not in accordance with Válek's results. The knowledge regarding significant runoff responses from the forested catchment was confirmed by analysis of chosen rainfall-runoff events. Forty events, which were chosen on the base of given criteria, were included in the analysis for now. Runoff events with more than one peak and the events, whose peak discharges on the base of measured rating curve was not reliably derived, could not be included in the analysis due to the criteria. Our further research will be also focused on these types of events. Despite their less frequent occurrence, their effect and their subsequent manifestations are sometimes of much greater importance.

Supposing identical precipitation input for both monitored paired catchments, four types of causal situations were defined. Even though there were not proved any differences statistically in parameters of rainfall-runoff events, detailed analysis warned about some differences. They were quantified using own classification. While comparing chosen hydrograph parameters for both catchments, we found out that the time of duration of the recessing limb of the runoff wave, and thus of all the rainfall-runoff episode, is longer in the forested TET. In the same way, there is usually a bigger runoff volume and the size of a discharge peak in the forested catchment. Rothacher (1973) reached similar results from the viewpoint of higher discharge peak in a forested catchment when he was doing his research in Oregon in the USA. The occurrence of a higher discharge peak was 
conditioned by increased saturation of the forested catchment. Higher discharge peaks in the grassy ZBY were recorded only during short-term rainy periods of big intensity and with higher saturation of the catchment. The influence of different vegetation cover for chosen rainfall-runoff episodes was not clearly proved by the study of the experimental catchments of the Modrava in the Šumava Mountains either (Pavlásek, Máca, Ředinová 2006). All the results showed relatively identical runoff response of the researched catchments.

But why does the observed forested catchment show higher runoff variability than predominantly unforested catchment? It is well known from similar research studies that together with increasing extreme rainfall-runoff event, the influence of vegetation on the duration of runoff process is decreasing and even other factors can make a contribution substantially. We could find some clarification of the different runoff response in the case of monitored paired catchments above all in soil environment, which is the fact confirmed by Hümann et al. (2011). Its spatial and time heterogeneity, different soil characteristics (mainly physical ones) influencing infiltration, retention and transport of water in the soil have a bigger effect on runoff formation than a different forest type does (Tesař, Šír, Dvořák 2004). Different water transport in the soil mechanisms can cause, after reaching full saturation of soil profile, fast runoff which can lead to extreme draining of the whole system even during small precipitation events (Šanda et al. 2006, Císlerová 2003).

Besides larger occurrence of soils with low hydraulic conductivity, greater extent of waterlogged areas in the forested catchment can play an important part during the generation of runoff depending on the level of immediate catchment saturation. The level of ground water in hydromorphic soils can play an important role primarily in places where it is almost all the year round close to the surface and it creates in this way minimal space for retention (Boorman, Hollis, Lilly 1995; Evans et al. 1999; Vlček et al. 2012).

In the monitored area, the system of open trenches and subsurface pipe drainage system have not been clarified from the point of view of their contribution to the velocity and the size of its runoff in the monitored area. Relatively rapid runoff response to the rainfall supports the hypothesis that the fast subsurface runoff from soft soil profile on the slopes of the catchment is the source of concentrated catchment runoff which is significantly accelerated in the network of forest trenches. The similar phenomenon was monitored by Šanda et al. (2006) in the experimental catchment of the Uhlířská in the Jizera Mountains. At the same time drainage creates conditions for rapid outflow of redundant water volume from soil gravitational pores. Created and enabled infiltration and retention of precipitations in a soil profile have positive impacts on runoff formation. On the one hand, it changes surface runoff into subsurface one using the infiltration and thus it prevents from dangerous concentrated runoff causing soil erosion, and on 
the other hand, the retention of the part of precipitations decreases the maximum of higher discharge waves (Černohous 2006). We can assume that functional subsurface drainage pipe systems in the ZBY could reduce the runoff response by their enlargement of retention space in soil. On the other hand, surface drainage channels in the forested TET can highlight the runoff response.

\section{Conclusion}

The submitted study brings findings from the first six-year period of monitoring of precipitations and runoff in the experimental area of Zbytiny in the headwater area of the Blanice River. Hydrological balance and runoff variability of two neighbouring subcatchments of the Zbytinský and the Tetřívčí Brooks are assessed on the base of comparative paired catchment research. From the point of view of their natural habitat, both brooks are almost identical, but they have been differently used for many years.

The discovery of differences in a character of both hydrological systems can be regarded as the main result of this study. Differences are statistically provable in long-term runoff (balance) figures and indexes of the total runoff variability. The differences in runoff response during individual rainfall-runoff episodes fade away and the catchments respond similarly. Yet, in the forested catchment, there was recorded surprisingly higher runoff response to causal precipitations, which resulted in the higher runoff variability. Any direct impact of the vegetation cover on runoff formation was not proved in a short-term period. Existing results have stimulated further research heading towards our cognition of the effect of the other runoff influencing factors in both catchments. Besides vegetation cover, there is an impact of different representation of hydromorphic soils, permanently or temporarily wet areas and a current role of historic drainage pipe systems. This contribution is a good example of the fact why studies about the impact of vegetation cover often bring contradictory results. That is because all possible causes influencing runoff formation are not included in their assessments and also because the causes are not quantifiable and familiar enough. The contribution also points out to the complexity of the runoff formation study in headwater areas of our rivers and to the difficulty when considering all needed parameters. 


\section{References}

ANDRÉASSIAN, V. (2004): Waters and forests: from historical controversy to scientific debate. Journal of Hydrology, 291, 1-27.

ARCHER, D.R. (2007): The use of flow variability analysis to assess the impact of land use change on the paired catchments, mid-Wales. Journal of Hydrology, 347, 3-4, 487-496.

ARCHER, D.R., NEWSON, M. (2002): The use of indices of flow variability in assessing the hydrological and instream habitat impacts of upland afforestation and drainage. Journal of Hydrology, 268, 244-258.

BAKER, D.B. (2004): A new flashiness index: characteristics and applications to midwestern rivers and streams. Journal of the American Water Resources Association, 40, 2, 503-522.

BÍBA, M., CHLEBEK, A., JAŘABÁČ, M., JIŘÍK, J. (2001): Les a voda - 45 let trvání vodohospodářského výzkumu v Beskydech. Zprávy lesnického výzkumu, 46, 4, 231-236.

BLAŽKOVÁ, Š. (1991): Zhodnocení světových zkušeností s vlivem odlesnění na povodňový odtok z deště. Journal of Hydrology and Hydromechanics, 39, 1, 69-94.

BOORMAN, D.B., HOLLIS, J.M., LILLY, A. (1995): Hydrology of soil types: a hydrologically-based classification of the soils of the United Kingdom. Institute of Hydrology, Oxfordshire.

BOSH, J.M., HEWLETT, J.D. (1982): A review of catchment experiments to determine the effect of vegetation changes on water yield and evaporation. Journal of Hydrology, 55, 3-23.

BROWN, A.E., ZHANG, L., McMAHON, T.A., WESTERN, A.W., VERTESSY, R.A. (2005): A review of paired catchment studies for determining changes in water yield resulting from alterations in vegetation. Journal of Hydrology, 310, 1-4, 28-61.

CAMORANI, G., CASTELLARIN, A., BRATH, A. (2005): Effects of land-use changes on the hydrologic response of reclamation systems. Physics and Chemistry of the Earth, 30, 561-574.

CÍSLEROVÁ, M. (2003): Preferenční proudění ve vadózní zóně a formování hydrogramu odtoku. In: Šír, M., Lichner, L'., Tesař, M. (eds.): Hydrologie půdy v malém povodí. ČVUT, Praha, 103-110.

CROKE, B.F.W., JAKEMAN, A.J. (2001): Predictions in catchment hydrology: an Australian perspective. Marine and Freshwater Research, 52, 65-79.

CZELIS, R., SPITZ, P. (2003): Retence vody v povodí při povodních. Acta Hydrologica Slovaca, $4,2,233-241$.

ČERNOHOUS, V. (2006): Vliv hydromelioračního zásahu na odtok vody z lesního povodí. In: Jurásek, A., Novák, J., Slodičák, M. (eds.): Stabilization of forest functions in biotopes disturbed by anthropogenic activity, VÚLHM, Opočno, 545-557.

ENGLER, A. (1919): Untersuchungen über den Einfluß des Waldes auf den Stand der Gewässer. Mitteilungen der Schweizerischen Zentralanstalt für das forstliche Versuchswesen, 12, Schweizerische Zentralanstalt für das Forstliche Versuchswesen, Zürich.

EVANS, M.G., BURT, T.P., HOLDEN, J., ADAMSON, J.K. (1999): Runoff generation and water table fluctuations in blanket peat: evidence from UK data spanning the dry summer of 1995. Journal of Hydrology, 221, 141-160.

FOHRER, N., HAVERKAMP, S., ECKHARDT, K., FREDE, H.G. (2001): Hydrologic Response to Land Use Changes on the Catchment Scale. Physics and Chemistry of the Earth (B), 26, 7-8, 577-582.

FÜHRER, H.W. (1992): Paired basin studies on the Krofdorf Forest research area, Hesse/Germany. In: Robinson, M. (ed.): Methods of Hydrological Basin Comparison. Institute of Hydrology, Oxford, 72-81.

GARCÍA-RUIZ, J.M., REGÜÉS, D., ALVERA, B., LANA-RENAULT, N., SERRANO-MUELA, P., NADAL-ROMERO, E., NAVAS, A., LATRON, J., MARTÍ-BONO, C., ARNÁEZ, J. (2008): Flood 
generation and sediment transport in experimental catchments affected by land use changes in the central Pyrenees. Journal of Hydrology, 356, 245-260.

HEGG, C., BADOUX, A., WITZIG, J., LÜSCHER, P. (2004): Forest influence on flood runoff generation studied on the Sperbelgraben example. In: Maraga, F., Arattano, M. (eds.): Progress in surface and subsurface water studies at plot and small basin scale. $10^{\text {th }}$ Conference of the Euromediterranean Network of Experimental and Representative Basins (ERB), IHP/ UNESCO, Turin, 47-52.

HIBBERT, A.R. (1967): Forest treatment effects on water yield. In: Sopper, W.E., Lull, H.W. (eds.): International Symposium on Forest Hydrology, Proceedings of a National Science Foundation Advanced Science Seminar, Pergamon Press, Oxford, 527-543.

HINTNAUS, I. (2008): Změny ve vývoji krajiny v pramenné oblasti Blanice. Bachelor thesis, PřF UK, Praha.

HORNBECK, J.W. (1973): Storm flow from hardwood-forested and cleared watersheds in New Hampshire. Water Resources Research, 9, 346-354.

HÜMANN, M., SCHÜLER, G., MÜLLER, CH., SCHNEIDER, R., JOHST, M., CASPARI, T. (2011): Identification of runoff processes - The impact of different forest types and soil properties on runoff formation and floods. Journal of Hydrology, 409, 637-649.

IROUMÉ, A., HUBER, A., SCHULZ, K. (2005): Summer flows in experimental catchments with different forest covers, Chile. Journal of Hydrology, 300, 1-4, 300-313.

KLIMENT, Z., MATOUŠKOVÁ, M. (2009): Runoff changes in the Šumava Mountains (Black Forest) and foothill regions: Extent of influence by Human Impact and Climate Changes. Water Resources Management, 23, 1813-1834.

KOKKONEN, T.S., JAKEMAN, A.J. (2001): A comparison of metric and conceptual approaches in rainfall-runoff modelling and its implications. Water Resources Research, 37, 9, 2345-2352.

KŘÍŽ, V. (1978): Hydrologická analogie a její využití ke kvantifikaci změn hydrologického režimu řek zpơsobených činností člověka. Geografie, 83, 1, 33-39.

KUŘÍK, P. (2000): Vliv lesních porostů na extrémní průtoky. Zprávy lesnického výzkumu, 45, 2, 33-37.

LANGHAMMER, J., KLIMENT, Z. (2009): Water quality changes in selected rural catchments in the Czech Republic. Ekológia, 28, 3, 312-332.

LANGHAMMER, J., MATOUŠKOVÁ, M., KLIMENT, Z. (2013): Assessment of spatial and temporal changes of ecological status of streams in Czechia: a geographical approach. Geografie, 118, 4, 309-333.

MALÝ, A. (2009): Vliv rozdílného využití krajiny na srážko-odtokový proces v experimentálních povodích Zbytiny. Diploma thesis, PřF UK, Praha.

MCCULLOCH, J.S.G., ROBINSON, M. (1993): History of forest hydrology. Journal of Hydrology, $150,189-216$.

NIE, W., YUAN, Y., KEPNER, W., NASH, M.S., JACKSON, M., ERICKSON, C. (2011): Assessing impacts of Landuse and Landcover changes on hydrology for the upper San Pedro watershed. Journal of Hydrology, 407, 105-114.

OUDIN, L., ANDRÉASSIAN, V., LERAT, J., MICHEL, C. (2008): Has land cover a significant impact on mean annual streamflow? An international assessment using 1508 catchments. Journal of Hydrology, 357, 303-316.

PAVLÁSEK, J., MÁCA, P., ŘEDINOVÁ, J. (2006): Analýza hydrologických dat z Modravských povodí. Journal of Hydrology and Hydromechanics, 54, 2, 207-216.

PRUDKÝ, J. (2003): Analýza přirozené retence vody v povodí řeky Opavy při povodni v červenci 1997. Acta Hydrologica Slovaca, 4, 2, 248-254. 
ROBINSON, M., DUPEYRAT, A. (2005): Effects of commercial timber harvesting on streamflow regimes in the Plynlimon catchments, mid-Wales. Hydrological Processes, 19, 1213-1226.

ROBINSON, M., WHITEHEAD, P.G. (1992): A review of experimental and representative basin studies. In: Robinson, M. (ed.): Methods of Hydrological Basin Comparison. Institute of Hydrology, Oxford, 1-12.

ROTHACHER, J. (1973): Does Harvest in West Slope Douglas-fir Increase Peak Flow in Small Forest Streams? USDA Forest Service Research Paper, PNW-163, U.S. Department of Agriculture, Portland.

SAGHAFIAN, B., FARAZJOO, H., BOZORGY, B., YAZDANDOOST, F. (2008): Flood Intensification due to Changes in Land Use. Water Resources Management, 22, 1051-1067.

SIDLE, R.C., TSUBOYAMA, Y., NOGUCHI, S., HOSODA, I., FUJIEDA, M., SHIMIZU, T. (1995): Seasonal hydrologic response at various spatial scales in a small forested catchment, Hitachi Ohta, Japan. Journal of Hydrology, 168, 227-250.

SIKKA, A.K., SAMRA, J.S., SHARDA, V.S., SAMRAJ, P., LAKSHMANAN, V. (2003): Low flow and high flow responses to converting natural grassland into bluegum (Eucalyptus globulus) in Nilgiris watersheds of South India. Journal of Hydrology, 270, 12-26.

SILVEIRA, L., ALONSO, J. (2009): Runoff modifications due to the conversion of natural grasslands to forests in a large basin in Uruguay. Hydrological Processes, 23, 320-329.

STEDNICK, J.D. (1996): Monitoring the effects of timber harvest on annual water yield. Journal of Hydrology, 176, 79-95.

ŠANDA, M., HRNČÍř, M., NOVÁK, L., CÍSLEROVÁ, M. (2006): Vliv půdního profilu na srážkoodtokový proces. Journal of Hydrology and Hydromechanics, 54, 2, 183-191.

TESǍ̌, M., ŠÍR, M., DVOŘÁK, I.J. (2004): Vliv vegetačního porostu a jeho změn na vodní režim půd v pramenných oblastech Krkonoš. In: Štursa, J., Mazurski, K.R., Palucki, A., Potocka, J. (eds.): Geoekologické problémy Krkonoš. Opera Corcontica, 41, Szklarska Poręba, 30-37.

VÁLEK, Z. (1962): Lesy, pole a pastviny v hydrologii pramenných oblastí Kychové a Zděchovky. Práce a studie, 106, VÚV, Praha.

VLČEK, L., KOCUM, J., JANSKÝ, B., ŠEFRNA, L., KUČEROVÁ, A. (2012). Retenční potenciál a hydrologická bilance horského vrchoviště: případová studie Rokytecké slatě, povodí horní Otavy, jz. Česko. Geografie, 117, 4, 395-414.

VON STACKELBERG, N.O., CHESCHEIR, G.M., SKAGGS, R.W., AMATYA, D.M. (2007): Simulation of the hydrologic effects of afforestation in the Tacuarembo River basin, Uruguay. Transactions of the ASABE, 50, 2, 455-468.

WATSON, F., VERTESSY, R., McMAHON, T., RHODES, B., WATSON, I. (2001): Improved methods to assess water yield changes from paired-catchment studies: application to the Maroondah catchments. Forest Ecology and Management, 143, 189-204.

\section{SHRNUTí}

\section{Využití párového srovnávacího výzkumu pro hodnocení odtokové odezvy v rozdílně využívaných horských povodích: povodí horní Blanice, Šumava, Česko}

V podmínkách Česka je většina pramenných oblastí zalesněna a pravidelně se zde formují významné povodňové situace. To je jeden z hlavních důvodů, proč je studiu vlivu vegetačního pokryvu, potažmo lesa, na odtok věnována velká pozornost. Povodí horní Blanice na Šumavě 
bylo jednou ze zdrojových ploch ničivé povodně v roce 2002. Zároveň došlo v této pohraniční oblasti během minulého století $\mathrm{k}$ významným změnám ve využití krajiny.

Z těchto důvodů byla v květnu 2006 v katastrálním území obce Zbytiny založena katedrou fyzické geografie a geoekologie Př́rodovědecké fakulty Univerzity Karlovy v Praze experimentální povodí zaměřená na výzkum vlivu rozdílného krajinného pokryvu na odtokový proces. Jedná se o dvě sousední malá povodí s velmi podobnými fyzicko-geografickými a hydrografickými poměry, jenž se navzájem liší krajinným a půdním pokryvem. V povodí Zbytinského potoka převažují kulturní louky, v povodí Tetřívčího potoka naopak les. Základním kamenem experimentálního výzkumu je monitorovací sít, která umožňuje kontinuální monitoring hydrologických, hydropedologických a meteorologických veličin v časovém rozlišení 10 minut.

Předložená studie si klade za cíl zhodnotit rozdíly v chování obou hydrologických systémů, především v jejich reakci na příčinnou srážku. Oba hydrologické systémy jsou porovnávány na základě párového srovnávacího výzkumu jak z pohledu dlouhodobých režimových charakteristik a jejich variability, tak i z pohledu vybraných krátkodobých událostí.

Srážko-odtokové vztahy a rozdíly v odtokových odezvách obou povodí byly sledovány na principu black box ze dvou hledisek: (1) na základě průměrných bilančních charakteristik a míry variability odtoku, (2) na základě analýzy vybraných srážko-odtokových epizod. Variabilita odtoku byla posuzována kromě klasicky používaných metod (čára překročení průměrných denních průtoků, variační koeficient $C \nu$ ) také pomocí flashiness indexu FI a analýzy hydrologické disturbance. Hodnocení srážko-odtokových epizod bylo založeno na podrobné analýze hyetogramu a hydrogramu vybraných srážko-odtokových epizod. Za tímto účelem bylo v období 2007-2012 vybráno 40 srážko-odtokových epizod, které splňovaly předem daná kritéria. Pro každou z vybraných srážko-odtokových epizod byla vypočtena sada příčinných a závislých proměnných. S využitím metod vícerozměrné statistické analýzy (analýza hlavních komponent, clusterová analýza) byly stanoveny čtyři typy příčinných podmínek. Hodnoty sledovaných závislých proměnných byly následně mezi oběma povodími vzájemně porovnány a testovány dle stanovených typů př́ícinných podmínek.

První odhady hydrologické bilance ukázaly, že objemový součinitel odtoku v zalesněném povodí Tetřívčího potoka je výrazně nižší než v nezalesněném povodí Zbytinského potoka. Z hlediska variability odtoku se významnější rozdíly projevily: (1) v oblasti nízkých průtoků, kdy zalesněné povodí, zejména v málo vodných letech, výrazněji nadlepšovalo průtok, (2) v oblasti vyšších průtoků, kdy zalesněné povodí, zejména ve vodných letech, vykazovalo výraznější odtokové odezvy. Větší variabilitu odtoku v povodí Tetřívčího potoka potvrdily v dlouhodobém horizontu i zvolené statistické indexy.

Při analýze jednotlivých srážko-odtokových epizod nebyly nalezeny žádné statisticky významné rozdíly v odtokové odezvě obou povodí. Přesto však byly detekovány některé odchylky, kterých je třeba si povšimnout. Doba trvání sestupné větve odtokové vlny a zároveň i celé srážko-odtokové epizody je při všech příčinných situacích u zalesněného povodí delší. S tím úzce souvisí i objem prrímého odtoku, který je rovněž u zalesněného povodí celkově větší. S poklesem nasycenosti povodí vzrůstá rozdíl v době od maximální intenzity srážky po dobu maximální kulminace odtoku ve prospěch zalesněného povodí. Největší rozdíl je zaznamenán u typu PS 1 , při vyšší nasycenosti povodí a déletrvajících regionálních deštích jsou rozdíly zanedbatelné. Velikost kulminačního průtoku se liší podle typu příčinných podmínek, přičemž důležitou roli hraje nasycenost povodí. Při nižší nasycenosti povodí, zejména při déletrvajících srážkách, byly sledovány vyšší kulminační průtoky u zalesněného povodí. Pouze během krátkodobých intenzivních srážek při vyšší nasycenosti povodí byly kulminační průtoky výrazně větší u nezalesněného povodí. 
Obr. 1 Poloha a vymezení párových povodí. Zdroj: PřF UK v Praze a WMS ČÚZK.

Obr. 2 Vývoj využití ploch ve sledovaných povodích (1949-2005). Zdroj: Hintnaus 2008.

Obr. 3 Meteostanice a hladinoměr - Zbytinský potok (vlevo), hladinoměr - Tetřívčí potok (vpravo).

Obr. 4 Odvozené měrné křivky průtoku pro Tetřívčí potok (a) a Zbytinský potok (b).

Obr. 5 Hodnocené vybrané charakteristiky hyetogramu a hydrogramu.

Obr. 6 Průměrné měsíční hodnoty odtokového koeficientu (2007-2012). Zdroj dat: PřF UK v Praze.

Obr. 7 Čáry překročení průměrných denních průtoků pro celé období 2007-2012 (a), pro málo vodné roky (b) a pro vodné roky (c). Zdroj dat: PřF UK v Praze.

Obr. 8 Počet (a) a celková doba trvání (b) pulzů pro vybrané prahové hodnoty průtoku (2007-2012). Zdroj dat: PřF UK v Praze.

\section{ACKNOWLEDGMENTS}

The presented research were conducted with the support of Czech Science Foundation, project No. 13-32133S "Headwaters retention potential with respect to hydrological extremes" and Ministry of Education, Youth and Sports, project No. LD15130 "Impact of landscape disturbance on stream and basin connectivity". 